\author{
Elżbieta SKĄPSKA, PhD \\ Faculty of Engineering Management, Bialystok University of Technology \\ e-mail: e.skapska@pb.edu.pl \\ ORCID: 0000-0003-0664-0917
}

DOI: $10.15290 /$ oes.2018.03.93.19

\title{
INNOVATIVE SERVICES OF COMPANIES IN PODLASKIE DISTRICT
}

\begin{abstract}
Summary
Goal - The aim of the paper is to examine the opinions of managers from Podlaskie district on innovations in services and to check whether the range of the provided services is accepted by service receivers.

Research methodology - The e-survey is directed at the managers of Polish companies in Podlaskie district. By means of the Pearson correlation coefficient, there was also performed another analysis which is related to the connections of the profile questions with the survey questions as well as between the questions that had been coupled.

Score - The research shows that the analyzed subsector of services is an interesting area in the context of innovations on the micro scale, and thus it has potential for further study. Local service industries that feature progressive services and flexibility factors towards customers have been identified here. Pearson's factor revealed the situations discourage managers to introduce progressive services on the market. Thus, the lower the degree of market saturation, the greater is the tendency to introduce those services. On the other hand, when the market assures prices that provide a high level of profitability, companies do not have motivation to introduce services of progressive character.

Originality/value - There has been no similar research in the literature. In the paper there have been identified local service industries that feature progressive services and flexibility factors towards customers. It constitutes a precious market recommendation that is necessary for the managers of service companies from Podlaskie district to make proper decisions.
\end{abstract}

Keywords: service enterprises, innovations in services, service manager, Podlaskie district

JEL classification: D11, D33, D70

\section{Introduction}

The openness of world economies, including the European ones, and market conditions have become the basis for the growth of entrepreneurship and innovativeness. Transformations occurred in various regions of a specific country. It is visible, among the others, in the fact that services are becoming more and more significant in the international trade. The phenomenon is being especially observed in the countries of The Visegrad Group: Czech, Hungary, Poland and Slovakia, where there are 10 main service categories that are covered by the World Trade 
Organization (WTO) statistics: transportation, travels, communication services, construction services, IT and information services, insurances, financial services, royalties and licence fees, other business services as well as culture and recreation services [Stefaniak-Kopoboru, Kuczewska 2016, pp. 265-284]. The significance of those categories is increasing in Poland, especially in Podlaskie district. There is a great deal of research based on similar indicators with regard to service contribution to export, import, service share in employment and in gross added value. The studies also regard the level of specialization in the international trade related to various types of services. However, the aforementioned research lack the opinions of practitioners on the subject of the parameters that define the development in services (which are below the macro level). This article aims at filling that cognitive gap.

The most important business component of contemporary economic entities is flexibility which expresses itself with the inclination for the introduction of changes depending on variable conditions of the environment. The economic practice and public activity prove that there is a need for intelligent growth. It consists in the growth of economy that is based on knowledge and innovation - the development which produces high added value. It requires considerable expenditures on research and development activity as well as applying the mechanisms that favor effective utilization of the theoretical knowledge in practice. Thus, it is necessary to foster creative entrepreneurship that introduces changes at the level of an enterprise and results in contributing to the creation of good economic condition in general.

The growth of contemporary economy is closely connected with innovations which drive the development and wealth. In order to create innovation, an innovative enterprise is established. It is understood as a unit that has produced innovation within the period of three years, i.e. it has introduced a certain novelty into practice with regard to a product (commodity or service), a process, marketing or organizing.

They augment competitiveness. Enterprises are the producers of innovations. Innovations are dependant on the creation of new knowledge and often become risky and costly. Entrepreneurs must pursue the utilization of new active solutions in order to minimize the costs, e.g. service offshoring [Pohulak-Żołędowska, 2016, pp. 451-466]. Thus, new forms of activity affect the transformation in the service structure by type not only at a national level, but also regionally and locally.

The article covers the issue of enterprises from Podlaskie district that tend to introduce innovation within the services of a higher level, understood as services, which creates added value from the standpoint of service company managers. It is important to understand that services are various human activities which create a market offer. It may constitute labor of an individual or an institution to the benefit of other individual or an institution. It is payable and it meets the consumer's demands [Skapska, 2016, pp. 183].

In order to realize their opinion on the subject of innovation in services, the survey method has been used. What is more, the paper also aims at recognizing the conditions in which progressive services are provided by enterprises. The aim 
includes the creation of the grounds for further study in the direction of pro-growth changes in the identified services. This paper has been divided into two main parts. The first one concerns the literature research. The second one includes the empirical part that presents the results of the research on the identification of service categories which belong to the field of progressive services as well as managers' opinions on the subject of their features and growth conditions.

\section{The essence and conditions for innovative entrepreneurship in services}

Services are considered as intangible because (in contrast to products), they cannot be received physically and may not be checked before their reception. In other words, service processes feature "fuzzy" information of intangible nature. It means they are not grounded in a material or physical structure. However, the heterogeneity of services concerns changeable results in the process of their provision. What is more, inseparability of services, with regard to their simultaneous provision and consumption, makes a client a co-producer who must be included in the aforementioned processes of provision and consumption. Services have transitional nature as they cannot be stored for further use, sold or returned [Biege et al., 2013, pp. 378-391].

The greatest significance of services may be found in the economies that are based on knowledge as they play a key role in innovative processes. Companies introduce a symbiotic relation with clients so that they become the co-producers of innovation. The main importance of this relation is the flow of information in its intangible form [Hertog, 2000]. The research connected with innovation traditionally focuses on production because services were not perceived as an important component of the productivity growth. Furthermore, many projects on services are directed at industrialized countries although, in many developing countries, services constitute the largest sector in economy and thus a crucial determinant of the economic growth. Though in many cases service companies are more innovative than production companies (both, as for the input and the output of "technological" innovative activity), the innovative services more often take a "non-technological" form [Zahler, Lacovone, Mattoo, 2014, pp. 953-979]. Various attributes of a service product are the key to drawing the attention of potential clients. It is connected with acting collectively, which may be simpler due to proper public policy that takes into consideration specificity of an innovation process and infrastructure of the sector [Aboal, Bravo-Ortega, Crespi, 2015, pp. 277-283].

Modern source literature underlines the point that a strategy oriented at delivering value to a client must be grounded on outstanding proficiency as a source of unique and persistent advantage over competition. Most processes regarding the added value stem from knowledge-based service activity. It is even suggested that all enterprises, including production companies, should define themselves as service enterprises as a client buys benefits and not products. 
Another generally known and a frequently mentioned standpoint rwgarding growth, is J. Schumpeter's theory on delivering value to a client. He claimed that "a basic fact is a process of creative destruction". It covers incessant revolutionization of an internal market. The destruction of an old economic structure creates a new one which stimulates the growth of productivity. A symptom of those internal transformations in an economy is the creation of new consumption goods, new methods of production and transportation as well as new markets. A symptom of entrepreneurship in services and in other sectors of an economy is the dynamics of founding new enterprises. The essence is the ability to increase the effectiveness of using resources for other fields of higher effectiveness.

Inclination for the introduction of innovation is particularly based on the cooperation of service companies in the vertical structure which is more favorable than the horizontal cooperation. The research prove that the influence of innovation on the innovation effectiveness is greater in service companies than in production companies. Career paths in professional companies affect the innovative skills. They serve as the indicators of innovation potential which is often neglected. The change of a career path is not "necessary evil", but it creates the solutions that are beneficial to receivers, as for adjusting life-work preferences of employees, and to a company - the growth of the innovation potential which is necessary for attracting and maintaining employees, however less for the growth of their efficiency [Malhotra, Smets, Morris, 2016, p. 369-393].

Thus, entrepreneurship constitutes the attitude of a unit which actively seeks for market opportunities, increases the degree of innovative skill use and introduces innovations. Entrepreneurship is also expressed in a number of newly-founded enterprises and in the growth dynamics of the already-existing ones. Theoretically, reaching the entrepreneurship growth is possible under condition of possessing the personnel that highly qualified, engaged in their work and able to flexibly conform to the changeable market requirements.

The dynamic growth of information technology and telecommunication goes along with the development of service trade abilities. The content of some services is processing, gathering and passing information. It includes such fields such as accounting services, personal data and pay processing, technical and legal advisory or different kinds of designing. Thanks to the digital technology of processing and passing information it has appeared that in those fields the processes of service production and utilization are not so closely connected with each other as they used to. Thus, the distance between a producer and a user is no longer a problem of the exchange.

One of the most prominent works regarding the adaptation of IT and communication in service business activity and their influence on the innovation is an inverted product life cycle by Barras. It begins with the introduction of primary process innovations which aim at the improvement of service provision efficiency. The next stage comprises the introduction of process innovations in order to improve the quality of services. The final phase is the introduction of product innovations [Barras, 1986, pp. 161-173]. Cooperation with various types of users and invest- 
ments in the knowledge management positively affects the current process innovations [Ashok, Narula, Martinez-Noya, 2016]. The point of view of Barras is shared by Evangelist, who claims that introducing the new evolution taxonomies into innovations in a service sector relates to pointing out different trajectories for various activity groups according to their technological aspect [Evangelista, 2000, pp. 183-222].

Companies that have competent employees and new technologies are more willing to introduce innovations and make decisions about entering international markets which is beneficial as for the growth expectations. Potential competition has a positive influence, as it has been stated in the research, on the product innovation and indirectly on the internationalization of companies from a service sector. What is more, in case of innovative entrepreneurs, business activity seeks one search for market niches [Castano, Mendez, Galindo, 2016, pp. 1690-1695].

The results of the research from the internationalized companies in the region of Andalusia in Spain that regard the internationalization factors for knowledge-based services, indicate that there are special advantages which are acknowledged by entrepreneurs. They include: service quality, personnel training, leadership and managing skills, innovations and technologies. The greatest significance can be attributed to those companies that engage themselves in foreign investments and observe their present clients and seek the new ones. The most important factors associated with a target market are: size, growth and the access to market [MunozGuarasa \& Pajares, 2014, pp. 144-164]. Thus creating a single market of services is one of the main aims within the scope of the improvement of economic growth. Moreover, one can observe incomplete cooperation within the movement of products, services and labor force as well as stopping the process of expansion [Skąpska, 2014, pp. 88].

\section{Research Methodology}

Many scientific papers underline the problems of regional economic condition and focus on particular macroeconomic indicators such as GDP, an unemployment level, a number of economic factors of medium-sized enterprises. Such research results might contribute to building strategic cooperation to the benefit of improvement in entrepreneurship processes. The differences between specific enclaves (i.e. regions), mainly result from historical divisions regarding the ways of producing GDP, demographic features, demographic conditions, natural conditions, transportation, infrastructure and size of foreign direct investments [Zimmermannova, Skalickova, Siroky, 2016, pp. 114-128]. However, macroeconomic effects are results of millions of decisions that are made by economic entities in the world, and the subject literature makes an effort to present the determinants of those decisions [López-Pérez, 2016, pp. 9-41]. The Eastern region of Poland has unique character in this respect and it is represented in the project realized by Podlaskie district.

The survey discussed in the paper is the initial research performed using the Internet and took place from November 2016 to January 2017. The purposes of the 
research were as follows: Firstly, to learn the opinion of service providers on a "progressive" service defined as an innovative one - compared with the previous years (a 5-year period); Secondly, to verify whether there is reason for creating ground for further research of this type. The survey was sent by electronic means to 4,000 managers of small and medium-sized service companies in Podlaskie district. However, only 41 companies participated in the research. It was random type research.

The analyzed group consisted in 41 managers from Podlaskie province service companies. The working experience was within the range of 11-20 years and above 20 years. $66 \%$ of the respondents were males and $34 \%$ of females. The research concerned classification of services and identification of stimulating and inhibiting factors affecting innovative actions in an enterprise from a specific trade. The respondents answered various questions concerning, for instance, introduction of progressive services, defining service receivers, adjusting a service offer to the needs, a level of profitability, inclination for introducing changes in service character, i.e. its quality in the nearest period of 1-3 years, and the factors that decide about extending an offer to include progressive services.

Receivers of progressive services are definitely young persons (44\%), persons with higher education (61\%) and local receivers (table1). As it was required by the project the last group of entrepreneurs, included the residents of a district, the province and the country. The least influential group of service receivers was foreigners $(5 \%)$ and persons with vocational education (12\%). Elderly persons and persons with secondary education had little participation. According to the managers of service enterprises (almost 71\%), service receivers describe the offered service standard as sufficient, and the offer appeals to their tastes and consumer needs $(93 \%)$. Despite an already-high degree of adjusting the offer to the receivers' needs, the managers of companies are prone to introduce changes in the nature of an existing service.

TABLE 1

The structure of progressive service receivers in Podlaskie district

\begin{tabular}{|l|c|}
\hline \multicolumn{1}{|c|}{ Progressive service receivers } & Percentile share \\
\hline With higher education & $61 \%$ \\
\hline Young person & $44 \%$ \\
\hline Local receivers & $37 \%$ \\
\hline With secondary education & $29 \%$ \\
\hline Elderly persons & $27 \%$ \\
\hline With vocational education & $12 \%$ \\
\hline Foreigners & $5 \%$ \\
\hline
\end{tabular}

Source: own elaboration based on own research results. 
The author of the survey described progressive services as contemporized services that aim at development. They are high standard, modern, innovative, concentrated on reaching a higher level of effectiveness in the context of company's growth. Progressive services are also creative, which means they that on a specific change in a process, a product, a business profile and they use skills and talent.

\section{Conditions for introducing changes in services by service providers - the results}

The performed research concludes that in Podlaskie district over $80 \%$ of the surveyed people introduced the services that belong to the aforementioned service activity category. The question whether the surveyed had introduced a service of progressive nature into their businesses was answered with "definitely yes" by $15 \%$, "rather yes" by about $27 \%$, "partially" - 37\%. As for this type of service, i.e. progressive service, $12 \%$ of respondents were not interested at all and about $10 \%$ of them said "rather not".

Surprisingly, many companies (almost 80\%) do not perform their own marketing research. Only $5 \%$ of them commission the external companies conducting such research to the external companies.

The pro-innovative attitude of enterprises is mostly positively affected by the following factors (table 2): flexible working hours, larger-than-average profitability of new services and personnel's inclination for empathy towards a client. The least significant role in the group of determinants, according to the managers, is played by: equipping a job post with ICT devices, a job with a progressive position and employment stability.

TABLE 2

Managers' opinions on the stimulating factors that affect the inclination for extending a service offer with the progressive services (in \%). 1 - means insignificant influence of the factor, 5 - very large influence of the factor

\begin{tabular}{|l|c|c|c|c|c|}
\hline \multicolumn{1}{|c|}{ Factor } & $\mathbf{1}$ & $\mathbf{2}$ & $\mathbf{3}$ & $\mathbf{4}$ & $\mathbf{5}$ \\
\hline Large market needs & $7.32 \%$ & $9.76 \%$ & $34.15 \%$ & $29.27 \%$ & $19.51 \%$ \\
\hline $\begin{array}{l}\text { Larger-than-average profitability } \\
\text { of new services }\end{array}$ & $9.75 \%$ & $12.20 \%$ & $31.71 \%$ & $21.95 \%$ & $24.39 \%$ \\
\hline Personnel creativity & $12.20 \%$ & $19.51 \%$ & $26.83 \%$ & $29.27 \%$ & $12.20 \%$ \\
\hline Progressive job position & $24.39 \%$ & $7.32 \%$ & $21.95 \%$ & $43.90 \%$ & $2.44 \%$ \\
\hline Employment stability & $19.51 \%$ & $2.44 \%$ & $29.27 \%$ & $34.15 \%$ & $14.63 \%$ \\
\hline Flexible working hours & $14.63 \%$ & $12.20 \%$ & $21.95 \%$ & $26.83 \%$ & $24.39 \%$ \\
\hline $\begin{array}{l}\text { Personnel's empathy inclination } \\
\text { for clients }\end{array}$ & $9.76 \%$ & $14.63 \%$ & $21.95 \%$ & $31.71 \%$ & $21.95 \%$ \\
\hline ICT equipment at a post & $12.20 \%$ & $7.32 \%$ & $46.34 \%$ & $31.71 \%$ & $2.44 \%$ \\
\hline
\end{tabular}

Source: own elaboration based on own research results. 
Finally, the strongest group of development barriers includes: lack of proper financial support, complicated administrative procedures, big competition, to a lesser extent, but still - lack of marketing research. The weakest influential force, in a negative sense, is found in the insufficient information about a market and in the lack of a proper target group.

TABLE 3

Selected descriptive statistics for the question of what factors decide upon the inclination to extend the service offer by adding progressive services

\begin{tabular}{|l|c|c|c|c|}
\hline \multicolumn{1}{|c|}{ Factors for introducing progressive services } & Average & SD* & CV** & Mode \\
\hline Q.9: Development barriers and large competition & 3.6 & 1.2 & 33.6 & 4 \\
\hline Q.15: The lack of proper financial support & 3.5 & 1.4 & 38.8 & 5 \\
\hline Q.1: Factors that stimulate large market demand & 3.4 & 1.1 & 33.2 & 3 \\
\hline Q.7: Staff empathy towards customers & 3.4 & 1.3 & 37.0 & 4 \\
\hline Q.2: Superior profitability of new services & 3.4 & 1.3 & 37.2 & 3 \\
\hline Q.6: Flexible working hours & 3.3 & 1.4 & 41.0 & 4 \\
\hline Q.5: Sustainability of employment & 3.2 & 1.3 & 40.8 & 4 \\
\hline Q.16: Complicated administrative procedures & 3.2 & 1.4 & 43.4 & 3 \\
\hline Q.3: Creativity of staff & 3.1 & 1.2 & 39.4 & 4 \\
\hline Q.8: ICT equipment at work post & 3.0 & 1.0 & 32.8 & 3 \\
\hline Q.11: Insufficient information on needs & 3.0 & 1.3 & 43.5 & 3 \\
\hline Q.10: Lack of marketing research & 3.0 & 1.4 & 47.3 & 3 \\
\hline Q.13: Poor traffic at service outlet & 3.0 & 1.3 & 43.5 & 3 \\
\hline Q.4: Job with progressive position & 2.9 & 1.3 & 43.5 & 4 \\
\hline Q.12: Irrational employment & 2.8 & 1.3 & 45.3 & 3 \\
\hline Q.17: Lack of proper target group & 2.8 & 1.3 & 46.6 & 3 \\
\hline Q.14: Local government difficulties (obtaining licence) & 2.5 & 1.4 & 53.7 & 1 \\
\hline
\end{tabular}

* Standard deviation; ** Coefficient of variation;

Source: own elaboration.

In case of the question, the scale had 5 ordinal degrees, whereas several measures were calculated for the descriptive statistics. Subsequently, particular question factors were ordered in the descending order in relation to the arithmetic average of the given answers. The results are presented in the table 3. According to the surveyed people, among the decisive factors with regard to the inclination to extend the service offer by adding progressive services, the greatest impact was made by the development barriers and large competition (3.6 on average), whereby these factors were indicated as number 4 on a 5 -degree scale. The variation of answers to this question was at a low level. The lowest average of answers, meaning low influence of a factor, was reached by difficulties by the local government 
(2.5 average). The mode of indications was 1 , whereby the variation of answers for this factor resulted in the highest value (CV 53.7\%). It may indicate various experiences of company owners depending on the district.

The performed analysis regarded the relations among the questions from the metric and the questions from the survey as well as the relations between the paired questions. In order to measure features on the nominal scale, Pearson's chi-squared test was used together with Cramer's V coefficient. As for features that were measured on the ordinal scale, Spearman's coefficient was used together with its significance test. The analysis resulted in the conclusion that, in two cases, the questions from the metric constructed the relations with other questions. It concerned the notion of 'education' and the question of 'whether the standard of service quality is sufficient' as well as the service category and its relation to the issue of whether a company fulfills the tastes and needs of receivers. In both cases, the author concluded that the relations, despite their statistical significance, have no cognitive value. In the instance of the relation between paired questions there was a statistically significant link between question 10: 'What is the level of market saturation as for your services?' and question 4 ('Do the prices that are shaped by the national market provide a high level of profitability?) and question 9 about the level of competition intensity in the trade. The analysis of the questions 10 and 4 shows that the high market saturation, as for progressive services, influences the level of prices that are shaped by this market, and thus, it does not provide a high level of profitability $(\mathrm{R}=-0.403 ; \mathrm{p}=0.009)$. In the second case (questions 10 and 9), the outcome was easy to predict - higher market saturation with progressive services corresponds to a higher level of competitiveness $(\mathrm{R}=0.43 ; \mathrm{p}=0.005)$.

TABLE 4

Progressive service ranking characteristic of Podlaskie district

\begin{tabular}{|l|c|}
\hline \multicolumn{1}{|c|}{ Service type } & Percentile share \\
\hline Advisory & $39.02 \%$ \\
\hline Training & $29.27 \%$ \\
\hline Construction & $19.51 \%$ \\
\hline Trade & $14.63 \%$ \\
\hline Medical & $14.63 \%$ \\
\hline Legal & $9.76 \%$ \\
\hline Advertising & $9.76 \%$ \\
\hline Design & $7.22 \%$ \\
\hline IT & $4.88 \%$ \\
\hline Information & $4.88 \%$ \\
\hline Hairdressing & $4.88 \%$ \\
\hline Recreational & $2.44 \%$ \\
\hline Cleaning & $2.44 \%$ \\
\hline
\end{tabular}

Source: own elaboration based on own research results. 
During the research, the following service categories have been identified (table 4): advisory, training, medical, trade, IT, tourism, transportation, construction, legal, recreational and others that covered: hairdressing, design and cleaning services.

The greatest number of entrepreneurs that opt for the progressive services represented the following service categories: advisory - almost $40 \%$ of the surveyed, training - about $30 \%$, construction - about $20 \%$ and medical - almost $15 \%$. In turn, the group of the least interested in the above services included managers from the tourism trade, hairdressing and cleaning - only $2.5 \%$.

Almost $40 \%$ of the surveyed declared introduction of specific changes in the nature of a service, its quality in the nearest period of 1-3 years. The changes cover:

1) more automated search for clients;

2) extending online offer;

3) purchase of software;

4) creating 365/24 service which is round-the-clock emergency service;

5) constant software and calculation method update;

6) training the personnel in accordance with clients' needs;

7) possibility of online ordering;

8) shortening realization/delivery time;

9) innovative approach to a client, extending a service catalog;

10) machinery park development;

11) BIM (Building Information Modeling) - innovative CAD software;

12) increasing the standard of provided services;

13) online service.

Thus, it is worth noticing the fact of mature recognition of market needs. Despite little investments in the marketing research, company managers know their receivers and their needs. Seeing convergence of opinions of various service company representatives it is noticeable that the answer to the market's needs, according to the most important companies, is a broader access to online services and introduction of new programs that improve serving customers.

\section{Conclusions}

The aforementioned results of the performed research allow one to conclude that the analysis of the activities that aim at the development of service business does not exhaust the topic sufficiently as for the issue of progressive services at a regional level. However, those research results solve the problem of the cognitive gap concerning the structure of services and the tools for making economic decisions of special importance to regional entrepreneurs. The region itself has its specific pro-innovative character. There is a need for in-depth quality research that will cover particular parameters specified by managers and other provinces of the country. Against the background of common data on service categories on the scale of the whole Polish economy, one might point out that the research-identified types of services do not reflect themselves in the macro economy. The leading services in 
the fields of innovation and competitiveness on the globalized Polish market are mostly: IT services, information services, financial services, insurance or legal services. Instead, at the level of the analyzed district, the leading services include advisory and training services, construction and trade. The last one is regarded as a component of the classic service group.

The summary of the research analysis makes it possible to present the following statements:

1. The entrepreneurs from the analyzed collectivity take into consideration a longer period of time when a client can access services which is obtained by extending the working hours to 24 hours a day.

2. The personnel training in accordance with clients' needs is considerably influential on the inclination for introducing a progressive service which is also practiced by regional service companies in the world.

3. Managers' attitude as for meeting clients' needs by adding them in the process of service provision is an important aspect of innovative activity in services.

4. The internet is perceived as a tool for maintaining bonds with a client who becomes a co-innovator.

5. Advisory, training and construction service trades belong to an innovationoriented group of service companies in the context of progressive services.

6. In managers opinion, employees do not search for the stabilization that is connected with a single job position. They value the prospect of changing a job more than a job with a progressive post.

7. Over-than-average profitability of introducing new services is the main reason for managers to introduce services of added value.

8. The lack of proper financial support from the central and local government institutions is discouraging.

9. A proper and complex measurement of the innovation results has key significance for boosting the investments in production and use of new knowledge.

10. Pearson's factor revealed the situations that either encourage or discourage managers as for the introduction of progressive services on the market. Thus, the lower the degree of market saturation is, the greater is the tendency to introduce those services. On the other hand, when the market assures prices that provide a high level of profitability, companies do not have the motivation to introduce services of progressive character.

Thanks to the results of the concluded research one may distinguish contemporary trends in business activity in Podlaskie district's service sector. They constitute indications for further considerations on the subject of progressive services that are regarded by the Author as the services of a higher level. Those services are directed at a particular group of receivers - highly educated, having above-than-average income and who are oriented at self-growth and self-realization within the range of higher-level needs as for a consumer hierarchy. The research allows one to define ground for an in-depth analysis of the above mentioned service category. This may 
result in strategic importance for the transformation of service enterprises in the conditions of global standards and requirements and it is valid not only today, but also in the nearest future - at least a decade. It is assumed that due to those results, service providers will be able to make pertinent economic decisions in order to obtain greater effects by means of considerably lower expenditures.

It needs to be stressed that due to a relatively small number of the respondents the research is considered to be a pilot study. Moreover, the research results solely concern the analyzed collectivity. Thus, they show only the outline of the issue without having a full effect on the entire population. This fact constitutes the motivation to conduct further studies.

\section{References}

Aboal D., Bravo-Ortega C., Crespi G., 2015, Innovation in the Services Sector, "Emerging Markets Finance \& Trade", no. 51(3).

Ashok M., Narula R., Martinez-Noya A., 2016, How do collaboration and investments in knowledge management affect process innovation in services, "Journal of Knowledge Management”, no. 20(5), DOI: 10.1108/JKM-11-2015-0429.

Barras R., 1986, Towards a theory of innovation in Services, "Research Policy", no. 15(4), DOI: 10.1016/0048-7333(86)90012-0.

Biege S., Lay G., Zanker C., Schmall T., 2013, Challenges of measuring Service productivity in Innovative, Knowledge - Intensive Business Services, "The Service Industries Journal", no. 33(3-4). DOI: 10.1080/02642069.2013.747514.

Castano M.S., Mendez M.T., Galindo M.A., 2016, Innovation, internationalization and business-growth expectations among entrepreneurs in the services sector, "Journal of Business Research", no. 6995, DOI: 10.1016/j.jbusres.2015.10.039.

Evangelista R., 2000, Sectoral patterns of technological Change in Services, Economics of Innovation and New Technology, no. 9(3), DOI: 10.1080/10438590000000008.

Hertog P.D., 2000, Knowledge-intensive business services as co-producers of innovation, "International Journal of Innovation Management", no. 4(4), DOI: 10.1142/S13639 $1960000024 X$.

López-Pérez V., 2016, Macroeconomic Forecast Uncertainty in the Euro Area, "Equilibrium. Quarterly Journal of Economics and Economic Policy", no. 11(1), DOI: 10.12775/ EQUIL.2016.001.

Malhotra N., Smets M., Morris T., 2016, Career Pathing and innovation in professional service firms, "Management Perspectives", no. 30(4), DOI: 10.5465/amp.2012. 0108.

Munoz-Guarasa M., Pajares E., 2014, Determinant Factors in the Internationalization of Knowledge-Intensive Services in a Peripheral Area, "Journal of Service Science and Management", no. 7(2), DOI: 10.4236/jssm.2014.72012.

Pohulak-Żołędowska E., 2016, Innovation in Contemporary Economies, "Oeconomia Copernicana", no. 7(3), DOI: 10.12775/OeC.2016.026. 
Skapska E., 2014, Development of the Service Sector in Poland at the turn of the century. Tendencies, determinants, perspectives, Saarbrücken: LAP Lambert Academic Publishing.

Skapska E, 2016, Ustugi w SGR, [w:] Leksykon spotecznej gospodarki rynkowej, Famielec J., Szplit A. (red.), Instytut Zarządzania Uniwersytetu Jana Kochanowskiego w Kielcach, Kielce.

Stefaniak-Kopoboru J., Kuczewska, J., 2016, Export Specialization in Services of the Visegrad Countries, "Equilibrium. Quarterly Journal of Economics and Economic Policy", no. 11(2), DOI: 10.12775/ EQUIL.2016.012.

Zahler A., Lacovone L., Mattoo A., 2014, Trade and Innovation in Services: Evidence from a Developing Economy, "The World Economy", no. 37(7), DOI: 10.1111/twec. 12117.

Zimmermannova J., Skalickova J., Siroky J., 2016, What Can Tax Revenues Tell us about the Economic Activity of Regions?, "Economics and Sociology", no. 9(1), DOI: 10.14254/2071-789X.2016/9-1/8. 